\title{
Effects of Land Ownership Disputes on Social Structure in Tehsil Dargai District Malakand
}

\section{Muhammad Nisar}

Lecturer, Department of Sociology and Gender Studies, Bacha Khan University Charsada, KP, PAKISTAN

*Corresponding Contact:

Email: muhdnisar74@gmail.com

DOI: $\underline{\text { https://doi.org/10.18034/gdeb.v7i1.104 }}$

\begin{abstract}
The main objective of this research study was to ascertain the effect of land ownership disputes due to land commercialization and its effects on social structure in Tehsil Dargai, Khyber Pakhtunkhwa, Pakistan. Out of 291 respondents from civil suit/1 register of Tehsil Dargai, a sample size of 128 respondents was selected randomly through using the Mwakaje (2013) formula. Convenience sampling was used as a tool for data collection. The dependent variable (social structure) was cross tabulated with independent variable (land commercialization related disputes). Association of variables was ascertained by using Chi-square test. The study found a significant association between social structure and land ownership disputes due to urbanization $(\mathrm{P}=.045)$, population pressure $(\mathrm{P}=014)$, land considered a key asset of livelihood $(\mathrm{P}=0.000)$, agricultural commercialization $(\mathrm{P}=0.000)$ and increase in land prices $(\mathrm{P}=0.000)$. However, there was a non-significant relationship between social structure and migration into an area $(\mathrm{P}=0.200)$. The study concluded that the social structure is becoming weakening due to land disputes because of commercialization. People are becoming materialistic in their outlook and feel no hesitation in adopting unfair means to sell or force encroachment on other's land which leads to the weakening of social bonds and hence social structure.
\end{abstract}

Key Words: Land, Land Commercialization, Social Structure, Disputes

\section{INTRODUCTION}

According to Rural Development Institute Report (2009) land is a vital asset, especially in the developing countries, particularly for the deprived people. Majority of the rural poor depend on agriculture for their existence. Further, both conventional and formal rights to land act as a structure of economic entrée to important markets and as a form of social entrance to nonmarket institutions, like family circle and community-level_domination structures. Land possession gives economic contribution to agricultural production, as a source of revenue from rental or sale, and as assurance for credit that can be used for either utilization or investment purposes.

Anwar et al (2004) stated that according to Household Economic Integrated Survey (HEIS) 2001-2002 data, around 10.36 percent of the rural population of Pakistan is landless; 32.63 percent own under one hectare; 0.046 percent owns between one and two hectares; 0.0309 percent owns between 2-3 hectares and 0.0293 percent own 5 or more hectares of land. 
These disputes of land lead to the devastation of social structure. Radcliffe-Brown (1943) defined social structure as the network of actually existing social relations. Every person has some roles and responsibilities inside the social structure. According to USAID (2005) land is an outstanding, valuable, and fixed source of inadequate amount and is an essential constituent in the diverse and multifaceted social relations of production and reproduction in which disagreement among persons and groups are bred.

Cernea (1988) and Wallerstein (2012) examined that large-scale infrastructure projects necessitate access to land and need to secure possession. This encourages the people to confront the existing common property, land establishment, which is categorized by Mexican agrarian law as social property. Therefore, this property regime is at present viewed by development actors as a barrier to their capital investment purposes. As a result, land is appropriated by influential private actors through miscellaneous procedures of buying, leasing and illicit means which sometime lead to the forceful eviction of rural community, bargain resettlements, land-grabbing and force migration.

Platteau (1996) revealed that the issues of migration and identity, therefore, turn into mostly more important. As examined in numerous African states, the native people resist the shift of customarily hold family and community land to outsiders by committing acts of destruction, looting, blazing, and stealing of property and crops of new land proprietors. To the amount that estrangement of land to outsiders breaches social norms, hatred and pressure aroused in case of immigration, which can transform into unwrap hostility and land disputes. Migrations across-community, on the other hand, engages amalgamation of different tribes with their specific values and interior land dealings. This leads to collapse of pre-existing traditional institutions, and which, in the nonexistence of formal organizations, lead to disputes within the host communities. Van Donge (1999) studied some fundamental reasons, like population pressure, agricultural commercialization, as well as urbanization, have added to the growing number of land disputes, also the present land tenure structures in Africa may possibly not be well-resourced to decide such disputes.

IIED (1999) report revealed that like West African in Ghana usually, dispute over land is most strict and seems likely to deepen. The bulky migration, population expansion, population pressure, speedy urbanization, land scarcity, cash-crop led marketization, and increasingly politicized conflict over land have produced increased competition.

Wilson (2000) in Bougainvillean revealed that land ownership gives a strong place and voice in local as well as in national politics to the people. Land also holds an extraordinary importance as the place where the parents and ancestors of the people are buried. In this extensively statement from 1974, close connection with their land was expressed by three Bougainvillean students that land is our life. The Land is our physical life and we depend on land for foodstuff and sustenance. Land is our social life: for matrimony, social position, social safety and for politics we depend on land. Whilst you take away our land, you cut away the means of our survival. We have little or no experience of social existence without the land.

Zongo (2002) has found that speedy population expansion, joined with either inadequate chance for non-agricultural employment or, in some other areas, growing non-agricultural claim for land, is an important factor that causes land prices to be high, resulting in higher struggle for an inadequate amount of land available. This frequently leads to disputes generation after generation or between ethnic groups, particularly in situation where threat is high and land is considered as an important source of livelihood. 
UN-HABITAT/ OHCHR (2005) reported that the most complex land disputes are those that comprise corrupt land administration in a state. In numerous countries, indigenous population have been evicted at threat of being evicted because of the failure to be familiar with their rights to land or these rights are suspended by the state, and or take their property by force for public use or privatization of their lands by the government. In countries where the indigenous people have been underprivileged in the past for a long time of their land rights, there is the possibility of more severe land disputes that may arise even after decades or generations afterward.

The communities in Uganda "receiving" and "sending" based on their historical models of migration. Their main findings revealed that the likelihood of having a dispute over a parcel was $6 \%$ points higher in receiving than in sending communities and that disputes probability were higher in communities with many tribes. Land disputes by type revealed that where many tribes were in a community, the probability of eviction and inheritance disputes were higher but not boundary disputes. Under World Bank pressure, mechanized farming has expanded speedily to those areas which belong to pastoral communities. In 2001, entire area under mechanized agricultural increased by 60.6 percent. This brought far reaching implications and imposed severe dangers to the survival of commercial land rights leading to disputes in diverse parts of the country (Yamano \& Deininger, 2005; Egemi, 2006).

In Mongolia, the privatization of urban land resulted in relatively a number of numerous allotments of land due to illegitimated declaration and uncreative, ineffectual land administration agencies whose staff is partially lacking ability, and partly open for unsuitable practices. Resolutions of these disputes not have transparency and usually favor the wealthy and prosperous people possessing informal associations to particular decision makers. Another wrongdoing is the allotment of land located in the river bank as well as nearby protected areas of Ulaanbaatar to the wealthy people by corrupted high ranking civic officers. In Georgia, in the second round of privatization of agricultural land people faced different illegitimate methods in which during the auctions some people were excluded and some were given preference over other groups or individuals. This lobbyism and bribery during the privatization procedure contributed harmfully to the previously low confidence of Georgian nationals over their government. The Darfur dispute is an example of land dispute resulting due to miscellaneous changes and leading to a bigger dispute. Shortage of land due to environmental degradation and population pressure, and privatization are responsible for land disputes which brings negative consequences for people (Bokeria, 2006; Baatar, 2007; Wehrmann, 2008).

\section{LAND COMMERCIALIZATION AND LAND OWNERSHIP DISPUTES}

Table 1 identifies the relationship between land commercialization, land disputes and its effects on social structure. Almost half of the respondents i.e 62(48.4\%) believed that land ownership disputes occur due to urbanization. $80(62.5 \%)$ of the respondents said that population pressure on land is responsible for disputes, while $95(74.2 \%)$ of the respondents were of the view that land ownership disputes occur where land is limited and considered a key asset of livelihood. Beside this some respondents i.e 56(43.8\%) said that large scale migration to an area is also responsible for land disputes because of the scarcity of land. Similarly, 95(74.2\%) of the respondents favoured the statement that land ownership disputes increases with the agricultural commercialization while almost all of the respondents i.e 107(83.6\%) agreed that when the land price increases in an area, the disputes on the land increases. 
Table 1: Frequency distribution and percentages of responses towards land commercialization and land ownership disputes

\begin{tabular}{|c|c|c|c|c|}
\hline S.no & Attributes & Yes & $\mathrm{No}$ & Total \\
\hline 1 & $\begin{array}{l}\text { Land ownership disputes occur due to } \\
\text { urbanization }\end{array}$ & $114(89.1 \%)$ & $14(10.9 \%)$ & $128(100 \%)$ \\
\hline 2 & $\begin{array}{l}\text { Land ownership disputes occur due to } \\
\text { population pressure on land }\end{array}$ & $110(85.9 \%)$ & $18(14.1 \%)$ & $128(100 \%)$ \\
\hline 3 & $\begin{array}{l}\text { Land ownership disputes occur where land } \\
\text { is limited and consider a key asset of } \\
\text { livelihood }\end{array}$ & $119(93.0 \%)$ & $9(7.0 \%)$ & $128(100 \%)$ \\
\hline 4 & $\begin{array}{l}\text { Land ownership disputes occur when large } \\
\text { scale migration started to an area }\end{array}$ & $98(76.6 \%)$ & $30(23.4 \%)$ & $128(100 \%)$ \\
\hline 5 & $\begin{array}{l}\text { Lan Land ownership disputes occur due to } \\
\text { agricultural commercialization d ownership } \\
\text { disputes occur when cash crop led } \\
\text { marketization increases }\end{array}$ & $109(85.2 \%)$ & $19(14.8 \%)$ & $128(100 \%)$ \\
\hline 6 & $\begin{array}{l}\text { Land ownership disputes occur due to } \\
\text { increase in land prices }\end{array}$ & $93(72.7 \%)$ & $35(27.3 \%)$ & $128(100 \%)$ \\
\hline
\end{tabular}

\section{RELATIONSHIP OF LAND OWNERSHIP DISPUTES WITH COMMERCIALIZATION AND ITS EFFECTS ON SOCIAL STRUCTURE}

In the study respondents were asked about land ownership related disputes prevalence in the study area. They share with the researcher that urbanization has significantly caused many problems in the area which disrupts the prevalent structure of community. The relationship was found significant $(\mathrm{P}=0.045)$ with social structure. The results of Van Donge (1999) buttress the findings of the study, in which he opined that agriculture commercialization, population pressure and urbanization have added to the growing number of land disputes in Africa. Furthermore, a significant relationship $(\mathrm{P}=0.014)$ found between social structure and population pressure on land. Most of the respondents were of the view that population pressure on certain land leads to the disturbance of social structure. The results of IIED (1999) report buttress the findings of the study, in which the report revealed that like West African in Ghana usually, dispute over land is most strict and seems likely to deepen. The bulky migration, population expansion, population pressure, speedy urbanization, land scarcity, cash-crop led marketization, and increasingly politicized conflict over land have produced increased competition.

In Pakistan, the economy is agricultural based, but now a day the concerned commodity is converting to modern commercialized form, thus have created numerous disputes. The growing commercialized construction on land, enhanced its value. Therefore, in the study area it was found highly significant $(\mathrm{P}=.000)$ in association with the emergence of disputes and seen as an active factor for disrupting the social structure. The same findings were of the Zongo (2002) who said that that land disputes continues generation after generation in situations where threat is high and land is considered as an important source of livelihood.

Migration and land ownership disputes were non-significant $(\mathrm{P}=0.200)$ in association. The findings of the study negate the findings of Yamano \& Deininger (2005) who classified the communities in Uganda into "receiving" and "sending" based on their historical models of migration. Their main findings revealed that the likelihood of having a dispute over a parcel was $6 \%$ points higher in receiving than in sending communities and that disputes probability were 
higher in communities with many tribes. Land disputes by type revealed that where many tribes were in a community, the probability of eviction and inheritance disputes were higher but not boundary disputes. The utmost important factor, as considered, by the researcher were the rurality of the study area. Hence, large scale migration occurs here from rural to urban areas, that's why the issue of land disputes was not prevailed in the study area due to migration.

Land disputes and agricultural commercialization have a highly significant $(P=0.000)$ relationship with each other. Land disputes occur due to agricultural commercialization. As the study area is rural and agricultural based and now a day's agriculture is becoming more and more commercialized which brought disputes among people. The result confers the findings of Cotula, Toulmin, \& Hesse (2004) as well as of Van Donge (1999) who declares agricultural commercialization as an important contributing factor of land conflicts in Africa. Land is becoming a valuable commodity and an easy way of high income. Land is selling by people as the price is becoming high and high. That's why increase in land prices significantly affected land ownership disputes $(\mathrm{P}=0.000)$. The study of Yamano \& Deininger (2005) that land disputes in Kenya occurs due to increase in sales of land market

Table 2: Association between land commercialization related disputes and its effects on social structure

\begin{tabular}{|c|c|c|c|c|c|c|}
\hline \multirow{2}{*}{ S.N. } & \multirow{2}{*}{ Attributes } & \multirow{2}{*}{ Responses } & \multicolumn{2}{|c|}{ Social Structure } & \multirow{2}{*}{ Total } & \multirow{2}{*}{$\begin{array}{l}\text { Statisticl } \\
\text { Chi-square }\end{array}$} \\
\hline & & & Yes & No & & \\
\hline \multirow{2}{*}{1} & \multirow{2}{*}{$\begin{array}{l}\text { Land ownership disputes } \\
\text { occur due to urbanization }\end{array}$} & Yes & $107(93.1 \%)$ & $7(6.1 \%)$ & 114(89.1\%) & \multirow{2}{*}{$\begin{aligned} \mathrm{X} 2 & =4.015 \\
\mathrm{P} & =.045\end{aligned}$} \\
\hline & & $\mathrm{No}$ & $11(78.6 \%)$ & $3(21.5 \%)$ & $14(10.9 \%)$ & \\
\hline \multirow[b]{2}{*}{2} & \multirow{2}{*}{$\begin{array}{l}\text { Land ownership disputes } \\
\text { occur due to population } \\
\text { pressure on land }\end{array}$} & Yes & $104(94.5 \%)$ & $6(5.5 \%)$ & $110(85.9 \%)$ & \multirow{2}{*}{$\begin{array}{c}X 2=5.991 \\
P=0.014\end{array}$} \\
\hline & & No & $14(77.8 \%)$ & $4(22.2 \%)$ & $18(14.1 \%)$ & \\
\hline \multirow[b]{2}{*}{3} & \multirow{2}{*}{$\begin{array}{l}\text { Land ownership disputes } \\
\text { occur where land is } \\
\text { limited and consider a } \\
\text { key asset of livelihood }\end{array}$} & Yes & $114(95.8 \%)$ & $5(4.2 \%)$ & 119(93.0\%) & \multirow[b]{2}{*}{$\begin{array}{c}X 2=30.399 \\
P=.000\end{array}$} \\
\hline & & No & $4(44.4 \%)$ & $5(55.6)$ & $9(7.0 \%)$ & \\
\hline \multirow[b]{2}{*}{4} & \multirow{2}{*}{$\begin{array}{l}\text { Land ownership disputes } \\
\text { occur when large scale } \\
\text { migration started to an } \\
\text { area }\end{array}$} & Yes & $92(93.9 \%)$ & $6(6.1 \%)$ & \begin{tabular}{|l|}
$98(76.6 \%)$ \\
\end{tabular} & \multirow[b]{2}{*}{$\begin{array}{c}X 2=1.645 \\
P=0.200\end{array}$} \\
\hline & & No & $26(86.7 \%)$ & $4(13.3 \%)$ & $30(23.4 \%)$ & \\
\hline \multirow[b]{2}{*}{5} & \multirow{2}{*}{$\begin{array}{l}\text { Land ownership disputes } \\
\text { occur due to agricultural } \\
\text { commercialization }\end{array}$} & Yes & $105(96.3 \%)$ & $4(3.7 \%)$ & $109(85.2 \%)$ & \multirow{2}{*}{$\begin{array}{c}X 2=17.362 \\
P=0.000\end{array}$} \\
\hline & & No & $13(68.4 \%)$ & $6(31.6 \%)$ & $19(14.8 \%)$ & \\
\hline & \multirow{2}{*}{$\begin{array}{l}\text { Land ownership disputes } \\
\text { occur due to increase in } \\
\text { land prices }\end{array}$} & Yes & $91(97.8 \%)$ & $2(2.2 \%)$ & $93(72.7 \%)$ & \multirow{2}{*}{$\begin{array}{c}X^{2}=15.021 \\
P=0.000\end{array}$} \\
\hline & & No & $27(77.1 \%)$ & $8(22.9 \%)$ & $35(27.3 \%)$ & \\
\hline
\end{tabular}

\section{ConCLUSIONS AND RECOMmEndATIONS}

It is concluded that the people in the study area has a clear vision that land commercialization leading to the destruction of social structure. It is found that the powerful people were more involve in buying and selling of lands. Commercialization indulge more and more people in land's business. Further they used malpractices due to which the social structure was getting disturbed. The study suggested that through the computerization of land and inculcation of moral values, land disputes can be minimized and hence social structure could be saved. 


\section{REFERENCES}

Anwar, T., Qureshi, S. K., Ali, H., and Ahmad, M. (2004). Landlessness and Rural Poverty in Pakistan [with Comments]. The Pakistan Development Review, 855-874.

Baatar, B. 2007. Land Conflicts related to Land Privatisation in Mongolia. Case Study of Urban and Peri-urban areas. Unpublished Master's Thesis at the Centre of Land Management and Land Tenure, Technische Universität München.

Bokeria, R. 2006. Ongoing Process of Privatisation in Georgia. Transnational Crime and Corruption Center, Caucasus Office. Tbilisi.

Cernea, M. M. 1988b. Alternative Social Forestry Development Strategies. In J. Ives and D. C. Pitt (eds) Deforestation: Social Dynamics in Watersheds and Mountain Ecosystems. London: Routledge. 159-190.

Civil suit/1 register of Tehsil Dargai District Malakand

Cotula, L., Toulmin, C., \& Hesse, C. (2004). Land Tenure and Administration in Africa: Lessons of Experience and Emerging Issues, International Institute for Environment and Development, London.

Egemi, Omer. 2006. Land tenure in Sudan: challenges to livelihood security and social peace. In Land issue and peace in Sudan, edited by Galal-Eldeen El Tayeb. Khartoum, Sudan: Sudan Environment Conservation Society.

IIED.1999. Land Tenure and Resource Access in West Africa: Issues and Opportunities for the Next Twenty Five Years, London: International Institute for Environment and Development

Platteau, J.-P. 1996. The evolution theory of land rights as applied to Sub-Saharan Africa: a critical assessment. Development and Change, 27, 29-86.

Radcliffe-Brown, A. R.1940 Structure and Functiun in Primitive Society. Neu: York: Free Press.

Rural Development Institute Report on Foreign Aid and Development for the World Justice Project, 2009. Women's Inheritance Rightsto Land and Property in South Asia: A Study of Afghanistan, Bangladesh, India, Nepal, Pakistan, and Sri Lanka

United Nations Human Settlements Programme (UN-HABITAT), Office of the High Commissioner for Human Rights (OHCHR): Indigenous Peoples' Right to Adequate Housing. A Global Overview. Nairobi 2005.

USAID. 2005. Land and Conflict; a toolkit for intervention. Washington, DC: USAID Office of Conflict Management and Mitigation.

Van Donge, J. K. 1999. Law and Order as a Development Issue: Land Conflicts and the Creation of Social Order in Southern Malawi. Journal of Development Studies 36 (2): 48-70.

Wallerstein, I. 2012. Land, Space, and People: Constraints of the Capitalists World-Economy. Journal of World-Systems Research, 18(1).

Wehrmann, B. 2008. Land conflicts: A practical guide to dealing with land disputes. Eschborn: GTZ.

Wilson, C. Land Management and Conflict Minisation Sub-Project 1.1. The Pacific Islands Forum Secretariat LMCM project supported by AusAID and UNDP.

Yamano, T. \& Deininger, K. 2005. Land Conflicts in Kenya: Causes, Impacts, and Resolutions, Foundation for Advanced Studies on International Development /National Graduate Institute for Policy Studies Discussion Paper 2005-12-002.

Yamano, T., \& Deininger, K. (2005). Land Conflicts in Kenya: Causes, Impacts and Resolution. FASID Discussion Paper, 27.

Zongo, M. 2002. Land Conflict. World Bank Regional Land Workshop in Kampala, Uganda. 